Amilcar Torrão Filho

Pontifícia Universidade Católica de São Paulo, São Paulo, SP, Brasil

\title{
As peregrinações de uma pária de Flora Tristan e a construção de uma feminista
}

Resumo: Publicado em 1838, Pérégrinations d'une paria é um relato da viagem iniciática de Flora Tristan pelo Peru, em busca da proteção de sua família paterna, e é o primeiro livro que torna conhecida a sua autora. Neste artigo defendo a ideia de que o livro, assim como seu Nécessité de faire un bon accueil aux femmes étrangères (1835), elabora uma teoria da luta social, empreendida por Tristan em seu retorno à Europa, que tem como ponto de partida a liberdade da mulher adquirida pela liberdade de movimentos, pela possibilidade de viajar e de comparar a sua sociedade com as demais sociedades, adquirindo nesse processo consciência social e política.

Palavras-chave: Flora Tristan; viajantes; feminismo

\section{A viagem como autoconsciência}

Todo viajante, ao escrever seu relato de viagens, fala de um lugar determinado: um lugar social, que define a maneira de ver e compreender a organização política, social e econômica do espaço visitado; um lugar de gênero, que demarca uma determinada maneira de compreender a divisão social dos sexos, particularmente o lugar da mulher na sociedade; um lugar patriótico, o país ou a civilização com a qual o viajante se identifica, que interfere na maneira de ver a paisagem natural, urbana e moral das terras visitadas, que pode ou não se modificar a partir da experiência vivida no deslocamento. Isso sem falar de um lugar literário, de acordo com o tipo de narrativa que utiliza: diário, relato, narrativa epistolar, texto científico, itinerário ou, mesmo, ficção, que é utilizado como uma forma de construir sua persona, seu lugar autobiográfico ou literário; assim como uma memória de biblioteca que conforma, por suas leituras prévias, a maneira de ver o mundo e a sociedade. No caso de Flora Tristan, nascida no ano de 1803 em Paris e morta em 1844 em Bordéus, os múltiplos lugares desde os quais, ao mesmo tempo, descreve e explica o

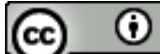

Esta obra está sob licença Creative Commons. 
Peru, constroem seu Eu autobiográfico como instrumento de "afirmação de uma identidade" (Brigitte MALENFANT, 1997, p. 34).'

A narrativa de Pérégrinations d'une paria, da viagem realizada entre 1833 e 1834 , e publicada em 1838, define os diversos lugares desde os quais a viajante olha o país sulamericano e a condição dos párias, da mulher em especial: de uma mulher descasada que vem de um país no qual o divórcio não é legal, onde seus direitos civis não são reconhecidos; de uma filha de pai hispano-peruano, o coronel da Armada espanhola Dom Mariano de Tristan y Moscoso, e de mãe francesa, Anne-Pierre Laisnay, considerada ilegítima por ser fruto de um matrimônio religioso, sem validade civil, realizado por um padre francês expatriado em Bilbao, Espanha, onde sua mãe vivia exilada; de uma herdeira sem herança nem recursos, desde a morte do pai em sua primeira infância, que realiza uma peregrinação em busca de reconhecimento de sua rica família peruana; de uma mulher em um mundo e em uma atividade, a de viajante e escritora, eminentemente masculinos; de uma francesa herdeira de valores ilustrados e revolucionários diante de uma nação em formação, recém saída da condição colonial e presa, ainda, em sua opinião, à origem malsã e infame da retrógrada cultura hispânica; de uma escritora sem grande instrução que desejava equiparar-se com ninguém menos do que George Sand, então um exemplo de femme de lettres bem-sucedida, mas sem utilizar o subterfúgio do pseudônimo masculino, que se distancia cada vez mais de seu modelo literário e políitico, radicalizando-se e afastando-se das posições mais contemporizadoras de Mme. Sand, que tampouco revela alguma simpatia por sua admiradora e seguidora.

Todos esses lugares se condensam em uma tipologia social que Tristan utiliza como uma espécie de couraça narrativa e política, um conceito de combate, que é a condição de pária, utilizada por ela como uma justificativa a suas deambulações de mulher descasada, assim como um mote de ação que Ihe constrói uma trajetória de ativismo político. Essa noção é fundamental, pois provoca uma verdadeira baralhada nos lugares desde os quais fala a viajante, sobretudo seu lugar social e seu lugar patriótico. Não é por acaso que Tristan se defina como pária, uma vez que esse conceito, como recorda Eleni VARIKAS (2014), inspirado nos dalits hindus, significa "uma raça estrangeira em sua pátria" (p. 28). Tristan se considera uma estrangeira em sua pátria de nascimento, uma vez que a situação política e social da mulher separada em seu país, sem direitos, sem dinheiro, ameaçada pelo ex-marido e sem reconhecimento social, Ihe obriga a buscar o auxílio de sua família estrangeira. Defensora dos valores ilustrados é estrangeira em relação à reação conservadora do Código Napoleônico, que atrincheirou a mulher na esfera da vida privada, afastada do espaço público e da política, à qual se dedicará todo o resto de sua vida depois da malograda viagem ao Peru. É estrangeira para sua família peruana não apenas por ser francesa, mas também por ser, a seus olhos, uma bastarda e ingrata, depois da publicação de seu relato de viagem muito pouco respeitoso com seus parentes americanos; estrangeira ainda por não compartilhar os valores escravocratas, católicos e senhoriais que identifica na maior parte dos membros de sua família e da sociedade peruana.

Sua posição como "estrangeira", como alguém que é alheio a um determinado entorno social, Ihe permite um olhar mais atento a alguns aspectos da sociedade peruana, um "Olhar de outsider" (Florence GABAUDE, 1998, p. 810) e um distanciamento em relação à sua própria cultura, ao mesmo tempo em que the permite neutralizar, por vezes, a desvantagem de sua condição de pária. Sendo francesa na América do Sul, ainda que não fosse totalmente aceita por sua família da elite peruana, acaba ocupando um papel social mais elevado do que o que ocupava na França, de mulher descasada, ilegítima,

' Todas as traduções são de minha autoria, salvo indicação em contrário. 
sem recursos e com pouca instrução. Colocada entre dois mundos, apesar de sua opção pela Europa, sua reconstrução pessoal se deve, para Stéphane MICHAUD (2007, p. 21), ao seu engajamento por uma identidade americana, além de um engajamento por uma identidade familiar incompleta por sua bastardia. Nesse sentido, Tristan ilustra perfeitamente a forma como Sara MILLS (2005) utiliza o conceito de "going native". Algumas vezes, viajantes adotam vestimentas e costumes dos povos colonizados, alinhando-se potencialmente aos locais, "traindo" a sua cultura original. Para Mills (2005), as mulheres viajantes estão colocadas num lugar intermediário, entre um discurso "colonial" e uma filiação aos "nativos", por mais problemática que essa filiação possa ser. Seus relatos, para esta autora, demandam um reconhecimento "da importância da interação com membros de outras nações, não como representantes da raça, como em relatos de autores masculinos, mas como indivíduos" (MILLS, 2005, p. 97-98). Flora Tristan está colocada desde o princípio neste lugar intermediário, pertencendo e não pertencendo à cultura do lugar visitado e narrado, numa viagem que desde o início tinha como objetivo "going native", tornar-se peruana e integrar-se à sociedade americana. A impossibilidade de pertencer totalmente à cultura francesa ou à cultura peruana lhe obriga a ocupar o lugar do pária, o que para ela viria a ser um caminho de libertação, uma terceira via para si mesma e uma possibilidade de conscientização dos subalternos.

Essa metáfora do pária já havia sido utilizada anteriormente por Bernardin de SaintPierre ou por Mme de Staël, que teria inspirado Tristan a utilizar este conceito (Christopher W. THOMPSON, 2012, p. 261). Para a autora suíço-francesa, o pária era a representação tanto do homem sensível em uma terra hostil e em tempos sombrios, quanto da mulher que vive entre homens, assim como os párias da Índia vivem entre as classes que lhes desprezam (VARIKAS, 2014, p. 34-39). Para Tristan, a metáfora do pária lhe permite construir um caminho político e reescrever sua biografia, redefinindo o papel secundário que sua condição de mulher lhe impunha. O pária, aqui, se por um lado ressalta seu papel secundário e subalterno, por outro serve para desmarcar-se de uma realidade social por sua injustiça intrínseca. A autoidentificação como pária reconhece um lugar social ao mesmo tempo em que clama contra a injustiça desse lugar e justifica à personagem em questão que se desmarque das instituições estabelecidas e das normas sociais aceitas, na medida em que desvela a injustiça de sua condição e os dispositivos que geram a desigualdade e a inferioridade que provocam a exclusão. De pária vitimizada ela se coloca no lugar de uma "pária reivindicada e sublimada" (GABAUDE, 1998, p. 810), uma forma de ter lugar na sociedade como agente de mudança.

Tanto a viagem empreendida por Tristan, que ela cuidadosamente intitula peregrinação, quanto o relato dessa via crucis são elementos de uma crise identitária marcada pela busca de autonomia e de um lugar social. O deslocamento no espaço, neste caso, como recorda Roland LE HUENEN (2015, p. 213) em relação aos relatos de viagem de Tristan, George Sand e Léonie d'Aunet, corresponde concretamente a uma liberação, "ao mesmo tempo a afirmação de si como sujeito, o poder libertador e constitutivo da tomada da palavra e o acesso pela escritura de uma nova identidade" (Cf. LE HUENEN, 2007, p. 82), construindo, assim, um lugar social e público a partir da reivindicação do papel de pária, um lugar de vítima e heroína ao mesmo tempo. Uma luta política justificada a uma mulher pelo papel central que a mulher pária tem, para Tristan, na revelação e na desmontagem das diversas desigualdades do mundo. Certamente apresentar-se como vítima tem um sentido reivindicatório que, em nenhum momento, representa alguma fragilidade, ao contrário: a pária de Tristan se apresenta como força catalizadora, como potência de vida e de ação, como altivez arrogante, muitas vezes. Como em sua insistência em ressaltar a sua "feminidade e respeitabilidade, que a leva a fazer duros comentários 
sobre as danças sensualmente 'indecentes' e as 'bufonarias' das negras e outras peruanas" (THOMPSON, 2012, p. 268). Por isso será chamada por seu amigo, o líder messiânico JulesSimon Ganneau, de "pária arquiduquesa" (Evelyne BLOCH-DANO, 2002, p. 266). Certamente ser pária não significa para ela uma debilidade inerente à sua condição feminina, mas o resultado de um processo de opressão e desigualdade que igualava mulheres, escravos e proletários mantidos igualmente à margem da sociedade. E a pária arquiduquesa tem certeza de que é a pessoa indicada para liderar e libertar todos esses desgraçados.

A afirmação de si como pária permitiu-lhe construir uma vocação política, a de femme messie do proletariado e do feminismo; ${ }^{2}$ em sua busca por uma identidade na América do Sul, isso poderia tê-la afastado da identidade europeia e francesa, tantas vezes questionada ao longo de sua peregrinação, quando procura identificar-se com sua origem peruana. Apesar das promessas não cumpridas de liberdade que a Revolução havia deixado à sua geração, sobretudo àqueles que defendiam ideias mais radicais como ela, no Peru, Tristan se descobre totalmente francesa e mulher pária, a partir de seus encontros com as mulheres peruanas, de origem europeia, africana e indígena, ainda que sua origem hispano-americana seja utilizada sempre que lhe seja conveniente. Ela utiliza o mundo não europeu, segundo Lloyd KRAMER (1992, p. 792), para estabelecer para si mesma um lugar na França como escritora e especialista. A viagem muitas vezes serve à construção de uma carreira intelectual ou profissional para europeus expatriados, uma especialização em um espaço ou em um tema pouco conhecido, na qual a experiência direta do viajante the proporciona autoridade em seu retorno ao país de origem. ${ }^{1}$ No caso de Tristan, sua "especialização" não será exatamente o Peru ou a América do Sul, mas a experiência da desigualdade dos párias, das mulheres e dos proletários. Em vez de se identificar, como se poderia esperar, com a condição pós-colonial da jovem nação peruana, liberada do jugo colonial espanhol, com a utopia de um Simón Bolívar que frequentava sua casa paterna em Paris, Tristan renova a identidade europeia com a qual havia saído do continente com a intenção inicial de não mais voltar.

A autoidentificação como pária, segundo Varikas (2014, p. 61), exprime um sentido de dignidade e orgulho, constrói, a partir do reconhecimento da exclusão, uma identidade positiva. A sociedade peruana, corrupta e decaída lhe oferece, no desprezo que, segundo ela, Ihe dedica à sua família, a oportunidade de definir-se como vítima que, apesar de tudo, resiste por conta de sua superioridade moral e cultural: sua fraqueza e inferioridade, bem como a sua condição de mártir, são virtudes que a colocam acima das demais mulheres e homens que não compartiliham a sua condição subalterna, ou que ainda não são conscientes da exploração a que estão submetidos. Seu sofrimento e sua consciência social a colocam nesse lugar superior de profetisa e de Messias que liderará o povo no caminho de salvação. Por outro lado, sua viagem, que segundo Ottmar ETTE (2008) Ihe abre a "um processo de aquisição de consciência modelado autobiograficamente" (p. 57), obriga-lhe a refazer a sua identidade francesa. Nessa época, diz a autora, justificando a visão eurocêntrica de sua descrição do Cabo Verde, escala de sua viagem ao Peru, "eu

\footnotetext{
${ }^{2}$ A atuação política de Flora Tristan está presente em outros relatos de viagem, como Promenades dans Londres (1840) ou Le Tour de France (1843-1844), que documentam sua atividade como líder do movimento operário. Esses relatos fogem ao objetivo deste artigo, que pretende estabelecer uma relação entre a experiência da peregrinação iniciática ao Peru, com a reconstrução de sua biografia e a formulação de um novo lugar social para a mulher pária por meio da liberdade de movimentos e de reflexão que permite a viagem, com a elaboração de sua consciência feminista e social. Meu interesse é tratar da formação de seu ideário político a partir desta experiência inicial da viagem ao Peru.

${ }^{3}$ É o caso, por exemplo, de Ferdinand Denis, no Brasil (Maria Helena ROUANET, 1991) ou Frederick de Waldeck, no México (Carolina DEPETRIS, 2014).
}

4 Revista Estudos Feministas, Florianópolis, 26(1): e43809 
era muito exclusiva: meu país ocupava mais espaço em meu pensamento que todo o resto do mundo; era com as opiniões e os usos de minha pátria que eu julgava as opiniões e usos de outros países" (2004, p. 83-84). Depois da peregrinação ao Peru, Tristan afirma ter aprendido que os homens são irmãos e que o mundo é uma pátria comum a todos. É com esse espírito universalista e cosmopolita, que não deixa de ser herança da llustração francesa, que ela entenderá a sua tarefa de ilustrar a seus compatriotas, a seus amigos e aos parentes peruanos.

\section{A peregrinação iniciática de Flora Tristan}

No Peru, Flora Tristan não encontra nem a promessa de integração em uma família, nem uma situação política que lhe proporcionasse uma condição social mais justa do que na França. Frente às imperfeições do sistema social e político peruano, às raízes hispânicas que lhe parecem saídas diretamente da legenda negra, ela reforça a defesa dos valores ilustrados. Sua crítica à aristocracia crioula, com sua conduta patriarcal e escravocrata, se transforma, segundo Michelle PERROT (2014), em um "protesto contra a opressão e toda forma de exploração: das mulheres e dos escravos" (p. 100). Ainda que a França de seu tempo praticamente não concedesse a esses valores um droit de cité, sua realização existia em potência, eles eram parte do patrimônio cultural compartilhado dos franceses, mesmo que estivessem esquecidos pelos governantes de seu país. Assim, ao voltar à Europa, Tristan se tornará uma ativista política em nome desses valores e de sua "conversão", promovida por sua peregrinação pelo grande oceano e pelos desertos sul-americanos. Se o Peru não pôde ser uma alternativa à sociedade francesa, sendo uma sociedade opressora contra todos os párias que nela viviam, mulheres, escravos, indígenas, a alternativa teve que ser a construção de um mundo novo no lugar que oferecia, pelo menos, melhores valores com os quais iniciar, ferramentas conceituais para a construção de um caminho de libertação. A liberdade que ela observa nas mulheres indígenas e nas limenhas é fundamental para a definição de seus ideais feministas ao compará-la com as restrições com as quais viviam as mulheres europeias. Ainda que essa constatação tenha servido para definir a França e a Europa como o lugar a partir do qual se poderia construir uma sociedade mais justa e igualitária - pelos valores fraternos que ela considera europeus -, a liberdade sem meios e sem instrução dessas mulheres Ihe permite defender o papel feminino no espaço público e na política, bem como a validade de seus direitos civis, a base da constituição de uma sociedade mais justa. Para ela, o Peru constitui, como recorda Ángela PÉREZ-MEJÍA (2004, p. 114), um laboratório para a formação política dessa líder do socialismo utópico.

As raízes ibéricas da América, a superstição, a cobiça, o despotismo impediam que o continente americano, o Peru de seus ancestrais, se tornasse a terra de promissão da femme messie proletária (Margaret TALBOT, 1991, p. 223). A peregrinação da pária francesa pela América do Sul permite que Tristan elabore uma teoria, uma visão política do mundo por meio da comparação entre mundos e entre experiências concretas, o que constitui, para Roxanne Leslie EUBEN (2006), "uma premissa subterrânea da teoria social ocidental moderna" (p. 24-25), a relação entre viagem e deslocamento e a elaboração de teorias políticas (Maquiavel, Morus, Tocqueville, entre outros exemplos dados pela autora, elaboraram suas teorias em contextos de viagem ou de exílio). Euben (2006, p. 11) define teoria como uma prática de investigação na qual a distância crítica tem papel fundamental; a teorização é uma atividade reflexiva exercida por pessoas comuns (viajantes) em determinados momentos. Para esta autora, as narrativas de viagem promovem essas mediações e permitem que os leitores testemunhem as pessoas comuns, os viajantes que, 
de boa ou má vontade, vão de encontro a um mundo estranho e diferente que lhes provoca um atrito desorientador entre o que eles pensam saber e o que eles ainda não sabem, e as aberturas e cercos que essa tensão, às vezes explosiva, produz, renovando o arsenal de ideias das sociedades (EUBEN, 2006, p. 12). No caso da peregrinação de Tristan, a viagem serve para que ela elabore um ideário político e uma militância. Colocando-se no papel de observadora, estabelecendo uma distância crítica em relação ao país que considera seu por adoção, assim como em relação a seu país de nascimento, ela se permite construir um aparato crítico e um projeto político que, em seguida, deixam de ser uma proposta de regeneração nacional para se tornar um projeto universalista de libertação das mulheres e dos proletários.

\section{A viagem como libertação}

Reconhecendo-se como pária, Tristan se identifica com todos os párias da humanidade, que não estão apenas na América, onde ainda existiam os mercados de escravos em praça pública, mas mesmo na Europa mais civilizada, na qual numerosas classes de indivíduos ainda sofriam uma opressão legal. É o caso dos camponeses na Rússia, dos judeus em Roma, dos marinheiros na Inglaterra, das mulheres por toda parte; pois "em toda a parte onde o fim do consentimento mútuo, necessário para a formação de um matrimônio não é suficiente para rompê-lo, a mulher vive em servidão" 4 (TRISTAN, 2004, p. 41). Tristan extrapola a sua situação pessoal, os sofrimentos de seu desafortunado casamento e separação, que redundariam numa tentativa de assassinato por seu exmarido, para construir uma tipologia de exclusão que parte da situação da mulher para constituir uma representação da exclusão e da desigualdade. Essa paixão, suas contradições, sua rebeldia, seu misticismo, fazem dela uma romântica, ou melhor, "uma heroína romântica, como se tivesse interpretado até o infinito a personagem que the propunha a sua época" (BLOCH-DANO, 2002, p. 181). Por isso, em 1835, três anos antes da publicação em livro de suas peregrinações, Tristan publica um opúsculo intitulado Nécessité de faire un bon accueil aux femmes étrangères, pela editora Delaunay. ${ }^{5} \mathrm{Um}$ texto de argumento curioso, a criação de uma associação de auxílio às mulheres que viajavam sozinhas, tanto estrangeiras quanto provincianas em viagem às grandes cidades. Trata-se de uma espécie de proposta de transição entre sua experiência como viajante solitária no Peru e seu ativismo social posterior.

Formam-se, aqui, duas das principais bases desse ativismo e de seu ideário político: a importância do exílio, do deslocamento e da viagem na construção de sua consciência social e a centralidade da situação social da mulher, de sua participação na vida pública, como condição para a constituição de uma sociedade mais justa. É pela experiência da mulher em exílio, incógnita em terra estrangeira sem poder desvelar sua verdadeira condição de mulher descasada, desprotegida pelas leis, vista com suspeição pela sociedade ao viver ou viajar sozinha, e pela própria necessidade de que a mulher em condição de fragilidade deva empreender por vezes verdadeiras fugas, que Tristan reconhece na viagem uma possibilidade de instrução, como foi para ela a viagem ao Peru, a Londres e o Tour de France, bem como de salvaguarda de suas liberdades individuais, fugindo de um exmarido abusivo, como foi o seu próprio caso. Ela deixa claro que este projeto nasce de sua

${ }^{4}$ Cf. BLOCH-DANO (2002, p. 272). Além da experiência peruana, as ideias de Charles Fourier, que utiliza o termo feminismo em 1837 e para quem ampliar os direitos das mulheres era o princípio do progresso geral, também influem em sua leitura da liberdade feminina, a metade do gênero humano, como princípio da liberdade humana.

${ }^{5}$ Sobre este texto pouco conhecido e pouco citado de Flora Tristan, cf. Martine REID (2014).

6 Revista Estudos Feministas, Florianópolis, 26(1): e43809 
própria experiência, da esperança de poupar às mulheres as mesmas dores pelas quais havia passado, "pois dessas mesmas infelicidades nasceu a ideia desse projeto, que poderia servir tão eficazmente à causa à qual servimos, a da humanidade" (TRISTAN, 1988, p. 85). Aqui já está claro para a autora que a questão da libertação da mulher é parte integrante de uma questão maior e universal, da libertação de toda a humanidade. Por isso, esse texto adianta também as proposições internacionalistas da autora e sua crítica ao nacionalismo, do qual não teremos espaço para tratar mais detidamente neste texto. ${ }^{6}$

A importância do papel da mulher na regeneração da sociedade, a partir de seus valores mais fraternos e solidários, cuja missão é "levar a paz e o amor ao seio das sociedades", se dá também pelo fato de que, apesar de constituir a metade do gênero humano, está condenada a viver em dor e em sofrimento (TRISTAN, 1988, p. 55-56). A autora apela à solidariedade para com as mulheres que se viam na preocupante situação de serem estrangeiras e sós; por isso dirige seu chamamento àquelas mulheres que não conhecem a infelicidade dessa condição e aos homens que não são capazes de compreendê-la (TRISTAN, 1988, p. 56). Sua afirmação de que os homens são incapazes de compreender a situação da mulher que viaja sozinha pelo mundo, por mais esforços que façam, significa que toda mulher é estrangeira e solitária no mundo diante desta outra metade da humanidade, que demonstra tão pouca empatia com essas párias. Mais do que um apelo à solidariedade com a mulher viajante, pouco frequente comparativamente aos homens que viajavam, seu opúsculo pretende ser uma defesa dos direitos da mulher e do caráter libertador da viagem e do deslocamento, uma reivindicação do direito à liberdade de movimentos das mulheres.

Pela viagem a mulher se educa, conhece o mundo, adquire experiência e, mesmo, uma profissão ou uma possibilidade de emprego, não esquecendo que Tristan trabalhou como dama de companhia de senhoras em viagem à Inglaterra; bem como uma possibilidade de escapar, como ela própria, de um matrimônio infeliz e de um marido violento, protegida pelo anonimato e pela solidariedade, à qual ela apela, para a proteção da mulher em situação de fragilidade. A autora percebe que a experiência do deslocamento pressupõe um desafio às mulheres, assim como evidencia a sua condição subalterna. Como observa Sara Mills (2005), a condição anômala da mulher viajante no espaço público produz um relato que revela "os traços de esforços discursivos sobre o lugar 'adequado' da mulher" (p. 106), uma permanente negociação entre o que pode ou não ser realizado e ser narrado. Tristan é consciente dessa anomalia da mulher viajante, da voz feminina no espaço público e, sobretudo, do espaço de luta e de engajamento político que a viagem representa, tanto no anonimato que permite à mulher quanto em sua capacidade de mobilização e libertação. Ela crê na viagem como elemento de propagação da revolução, o que teria acontecido a partir da Revolução Francesa, em 1789, com a sua missão de propagar a civilização pelo universo. Por civilização ela entende não apenas as leis e o sistema político criados pela Revolução, como as relações estabelecidas entre as nações, as trocas culturais que permitem que os ingleses não desdenhem mais o que provém do continente ou que a Itália não despreze o que vem de além-Pirineus, por exemplo (Flora TRISTAN, 1988, p. 68).

A mulher estrangeira, uma caluniada segundo Tristan, costuma ser uma mulher em situação de debilidade, de jovem enganada, abandonada e sem recursos, que deve fugir geralmente da província para as grandes cidades e capitais. Sua pobreza é o que Ihe obriga a viajar e fugir, e aqui Tristan (1988) identifica a condição dessa mulher só e empobrecida com um chamado à justiça: pois "só se engana e se ataca aos fracos e aos infelizes" (p. 62). Ainda que a mulher rica não costume se separar de seu marido pelo hábito

${ }^{6}$ Para este tema, consultar Barbara PAUK (2008). 
e pela conveniência, o que lhe mantém em situação de inferioridade, é a mulher pobre quem, nessa situação, costuma ser jogada na miséria. Sua proposta de auxílio à mulher estrangeira tinha como objetivo desfazer a injustiça da sociedade em relação a essas mulheres, vistas com desprezo e desconfiança, apesar das qualidades e virtudes que Tristan (1988) idealiza no sexo feminino: "costumes simples, ideias justas e qualidades sólidas" (p. 65). Este desprezo e desconfiança tinham quase sempre como resultado jogálas no caminho do vício, do precipício social; esta situação impede que essas virtudes naturais da mulher se desenvolvam.

Parte de sua estratégia política é afirmar a condição da mulher e de suas qualidades e virtudes intrínsecas como elemento de regeneração de toda a sociedade. E para isso é necessário que elas entrem no "santuário da instrução", abandonando a ociosidade em que muitas mulheres bem-nascidas viviam, sobretudo em Paris, não podendo se dedicar mais que a "ocupações frívolas e de pouca duração" (TRISTAN, 1988, p. 69). As viagens, nesses casos, instruem as mulheres sobre seu próprio país, sobre suas províncias e sobre o mundo, além de propagarem essas virtudes que Tristan atribui prioritariamente às mulheres. Se a Revolução se propaga pela viagem das ideias e das instituições, a viagem das pessoas, incluindo a das mulheres, renova os princípios da fraternidade entre os povos e entre os homens: "e essas viagens, essa hospitalidade recíproca, aproximarão muito mais o dia tão desejado quando nós seremos todos homens, irmãos, sem nos distinguir pelos nomes de ingleses, de alemães, franceses etc." (TRISTAN, 1988, p. 79).

\section{A construção de uma personagem: a mulher viajante}

Retornando ao relato da peregrinação de Flora Tristan pelo Peru, quero destacar três dimensões que são importantes para compreender como ela constrói uma noção de alteridade do mundo hispano-americano que é importante para a formação de seu ideário político. Inicialmente uma herança hispânica, representada pela má influência de uma religião de aparência e uma Igreja corrompida, refletida também nos maus costumes do povo e de suas elites, despotismo e cobiça que geram e mantêm a dominação. Em seguida, as desigualdades de gênero, quando a situação da mulher é ao mesmo tempo um reflexo da má organização social, como uma esperança de um devir social mais justo, representado pela liberdade e inteligência das mulheres limenhas, a liderança política de Pancha Gamarra e a força moral das indígenas. Finalmente, a precariedade do projeto pós-colonial da República peruana, marcado pela violência e pela rapacidade de suas classes superiores e pela fragilidade de suas instituições democráticas. Essas três dimensões do relato muitas vezes se confundem, pois são partes de um mesmo esforço de compreensão para a construção de um projeto político, reformador e civilizador para a sua pátria de adoção, a pátria de seu pai adorado e perdido tão precocemente, que serão componentes de uma reconfiguração autobiográfica e social, indicando, como recorda Le Huenen (2015, p. 200), o caminho de uma vocação intelectual totalmente nova.

Dedicado aos peruanos, como uma homenagem aos que considera seus compatriotas, seu relato tem também um sentido pedagógico: pela acolhida que recebeu no país, apesar de não ter recebido o refúgio e a posição que permitissem sua entrada em sociedade (TRISTAN, 2004, p. 49), como afirma no prólogo de seu livro, nem a herança pela morte de seu pai que esperava receber (THOMPSON, 2012, p. 265) e, posteriormente, de sua avó, decide fazer uma crítica à sua condição política e a suas elites, correndo o risco de ferir o orgulho nacional, para que pudessem "harmonizar seus costumes com a organização política que adotaram" (TRISTAN, 2004, p. 31), ou seja, adequar as práticas políticas e sociais a uma verdadeira república. Tristan (2004, p. 33) afirma que vê a América como o

8 Revista Estudos Feministas, Florianópolis, 26(1): e43809 
futuro, um lugar no qual os preconceitos da Europa, obstáculos ao progresso, teriam menos aderência. Apesar do tom de superioridade, a ideia de que a potencialidade da América era a possibilidade de cumprir os desígnios ilustrados e civilizatórios da Europa, valores já decaídos no Velho Continente, faz com que Mary Louise PRATT (1999) não veja em Tristan uma representante do que chama "vanguarda capitalista" (p. 252), viajantes que viajavam e escreviam como "batedores avançados do capital europeu" (Idem), descritores do fracasso das sociedades ibero-americanas, legitimando a ação do capital e produzindo informação útil aos interesses imperialistas das nações europeias. Tristan, assim como Maria Graham, por exemplo, representaria uma visão crítica, politizada e reformista muito mais interessada na compreensão do processo de construção nacional por meio da "investigação social como prática política" (PRATT, 1999, p. 276).

Outra questão importante no relato de sua peregrinação, que tem estreita relação com o seu Nécessité de faire un bon accueil aux femmes étrangères, é a reivindicação de sua condição feminina como argumento de autoridade de seu relato de viagem, daí sua crítica a escritoras e viajantes que, como George Sand, se ocultavam sob pseudônimos masculinos. Essa reivindicação contradiz uma tópica da narrativa de viagem em feminino, como recorda Bénédicte MONICAT (1996, p. 31), que era a necessidade de uma rejeição da feminidade da viajante, com ou sem nome masculino, e de conservar as aparências de inferioridade feminina como uma espécie de licença para a viagem e para a escritura; uma tentação, senão uma obrigação, como afirma Denise BRAHIMI (2012, p. 267), de uma virilização física e mental da viajante. Exercendo uma atividade em princípio vedada às mulheres, que era a viagem e a análise política e social, muitas viajantes assumiam um discurso paradoxal, que reforçava os papéis femininos tradicionais ao mesmo tempo em que justificava o seu direito ao deslocamento e à opinião, tendo que ser lidos esses textos levando em conta as suas contradições e paradoxos (Stella Maris Scatena FRANCO, 2008, p. 163). No caso de Tristan, o papel secundário da mulher é ressaltado mas, diferentemente da maioria das viajantes, como denúncia de uma ordem de injustiça generalizada com todos os débeis e fragilizados do mundo. A mulher em deslocamento, a viajante e investigadora social revela a injustiça dessa ordem que a autora desnaturaliza, ainda que muitas vezes se utilize de uma imagem da feminidade idealizada e caracterizada por uma essência feminina, diferente e superior à masculina, marcada por virtudes como "amor, altruísmo e integridade moral" (Susan GROGAN, 1994, p. 155), o que poderia levar ao aperfeiçoamento da humanidade por meio de sua feminização (Idem, p. 191).

Daí sua relação ambígua com George Sand, um modelo com o qual rompe apesar de ter sido uma das únicas autoras do século a poder cumprir o mandato de libertar a mulher de seus grilhões. Esse modelo não funciona, para Tristan, porque Sand e outras mulheres como Marie d'Agoult, conhecida literariamente como Daniel Stern, ocultam seus nomes femininos e, por conseguinte, sua condição feminina, mas também por terem optado pela ficção para esconder-se ainda mais. Flora opta pela narrativa de viagem autobiográfica com conteúdo social, embora tenha escrito uma novela, Mephis (1838), sem muita transcendência. Nas narrativas de suas viagens Tristan fala em primeira pessoa, revela constrangedoras conversas privadas com seus interlocutores, constrói sua argumentação política e social a partir de sua experiência pessoal, que ela utiliza como argumento de autoridade e uma arma de combate. Ao contrário de Sand, escreve com seu nome e conta sua própria vida, reivindicando a necessidade de uma absoluta franqueza; seu desafio é, como afirma uma de suas biógrafas, esse desejo de autenticidade (BLOCHDANO, 2002, p. 169); ainda que seja uma autenticidade marcada, em muitos momentos, por uma construção ficcional de sua personagem de pária e de mulher respeitável. 
Em lugar de afirmar a fragilidade feminina e colocar-se num lugar narrativo de humildade, como um pedido de licença para falar em público mesmo sendo apenas uma mulher, uma tática frequente nas escritoras do século XIX, até mesmo de algumas feministas, como ressalta Franco (2008), Tristan reafirma a inferioridade feminina não como um lugar natural, mas como um resultado da desigualdade. A viagem e a mobilidade da mulher pelo mundo não apenas explicitam esta desigualdade e suas causas, como também servem como estratégia de desconstrução dessa desigualdade ao evidenciar as travas que sofrem as mulheres e os exemplos nos quais a inexistência dessas travas revela os talentos e qualidades naturais do sexo feminino, como no caso de sua descrição das mulheres limenhas. A inferioridade da mulher não é, assim, nem uma natureza da mulher nem um impedimento ao seu desenvolvimento político ou social; ela é ponto de partida para uma militância, início de um caminho de libertação.

\section{A tarefa da Pária: a crítica social}

Seu relato segue muitas das sendas tradicionais da literatura de viagem, apesar de seu caráter particular, como observei antes. O catolicismo ibérico é um dos elementos mais notáveis aos viajantes do norte da Europa na América do Sul, visto como uma continuidade entre o mundo hispânico e lusitano e suas ex-colônias no continente. ${ }^{7}$ Ao descrever a procissão de Nossa Senhora, ocorrida em 24 de setembro, em Arequipa, Tristan observa que as festas religiosas, repletas de ostentação, são o único divertimento do povo. Ao vê-las, afirma, se pode ter ideia do que foram as saturnais e bacanais pagãs; para ela, a religião católica "nos tempos da mais profunda ignorância, jamais expôs à plena luz do dia tão indecentes bufonarias, desfiles mais escandalosamente ímpios". As bandas de músicos, o burlesco das representações teatrais, os negros e mestiços disfarçados de pierrôs e arlequins, as danças impudicas e obscenas a escandalizam. Uma magnificência que impede, em sua opinião, que seja possível espiritualizar o culto católico no país (TRISTAN, 2004, p. 272273). O barbarismo do espetáculo se consuma em seu anacronismo: a representação teatral da luta entre cristãos e sarracenos em torno da verdadeira fé, no alpendre da igreja, que atrai a quase todo o povo e que fazia a felicidade de sua prima Doña Carmen, era uma completa novidade para ela, "filha do século XIX, chegada de Paris", como se autodefine. Este espetáculo de "extrema ignorância, a estúpida superstição, levava minha imaginação à ldade Média", e ao que representa esse tempo à viajante ilustrada: ferocidade selvagem e fanatismo religioso exaltado, o mesmo que representava Victor Hugo em seu Notre Dame de Paris (TRISTAN, 2004, p. 274-275).

Sua leitura não é simplesmente religiosa, como é costume em viajantes, tanto católicos quanto protestantes, ao descreverem as cerimônias religiosas dos países ibero-americanos, nas quais uma religiosidade de aparência, sem verdadeira espiritualidade, mesclava as diversões mundanas com as festas sacras. O que Sérgio Buarque de HOLANDA (1988) definiu em seu Raízes do Brasil como "uma religiosidade de superfície, menos atenta ao sentido íntimo das cerimônias do que ao colorido e à pompa exterior, quase carnal em seu apego ao concreto e em sua rancorosa incompreensão de toda verdadeira espiritualidade" (p. 111 ), resultado para esse historiador de nossas mal plantadas raízes ibéricas. Assim como na interpretação de Holanda, Tristan considera essa religião de aparência como resultado de uma opção política de opressão do povo, uma maneira de mantê-lo em um estado de embriaguez, entretido em seus preconceitos; o clero, como recorda, ajudou a revolução, mas não quis perder seu poder, conservando-o por muito tempo ainda (TRISTAN, 2004, p. 277). Aqui ela aponta uma contradição do processo de independência peruano, uma

7 Cf. Amilcar TORRÃO FILHO (2010a, 2011). 
revolução que manteve os elementos retrógrados e, portanto, antirrevolucionários, de um clero desprovido de qualquer ilustração. Em lugar de simplesmente desdenhar esse triste espetáculo, como fazem outros franceses presentes, Tristan se coloca em outra posição, de observadora crítica, propositiva e reformadora social. Em lugar de rir, retorna triste do espetáculo, uma vez que desejava a felicidade do povo ao qual estava ligada e afirmava pertencer. Entristece-se ao ver que falta a instrução que poderia dar verdadeira forma à república, a única maneira de fazer aflorar as virtudes cívicas. No entanto, essa república foi criada para garantir o poder de alguns poucos e não a liberdade de todos; seus líderes se interessam apenas por continuar a obra do despotismo colonial que diziam abolir com a independência e manter a obediência do povo que eles, associados aos padres, exploram por meio dos preconceitos e da superstição (TRISTAN, 2004, p. 278). Ela assume que a situação do Peru é resultado de sua organização social estar baseada no modelo espanhol, embora não chegue a questionar, diz Carla FAINI (1997, p. 97), os modelos coloniais da França ou Inglaterra, que também eram sistemas de dominação.

A Igreja explora para seu benefício o gosto da população, tanto o clero secular como o regular, com procissões incessantes e, é claro, muitas esmolas. Todas elas burlescas, indecentes bufonarias que enriquecem a lgreja; mas nada se compara com as grandes saturnais do catolicismo peruano, a Semana Santa, uma confusão, um caos, um tumulto e desordem que não se poderia esperar encontrar em nenhum templo de nenhuma religião. Essas cerimônias representam extravagâncias, "uma devoção supersticiosa" de cabeças exaltadas. Na missa, os homens falam rindo, olhando as belas jovens ajoelhadas diante deles à moda oriental; elas, sempre distraídas, jamais levam um livro, ocupando-se de reparar na roupa de sua vizinha ou falam entre elas, ou ainda ficam deitadas sobre os tapetes, dormindo (TRISTAN, 2004, p. 319-321). A orientalização do mundo ibérico fez com que se buscassem nessas sociedades os elementos de um despotismo asiático, do qual a reclusão feminina, mulheres indolentes sentadas em tapetes, mantidas na ignorância e no analfabetismo, como as mulheres de Arequipa em suas igrejas, faziam parte integrante.

Esta orientalização do espaço americano significava, portanto, a identificação do mundo hispano-americano a uma civilização inferior, bárbara e anacrônica, em oposição aos valores europeus mais civilizados e uma deturpação do que esses viajantes, Tristan incluída, acreditavam ser o verdadeiro cristianismo. Essa incompreensão das formas espirituais da religião indica, do ponto de vista dos viajantes, uma incapacidade dos locais de reconhecer as diferenças entre o bem e o mal, entre a virtude e a infâmia, entre a civilização e a barbárie. No caso de Tristan, não deixa de ser contraditória a sua leitura do catolicismo peruano: se de um lado critica ferozmente a ação da lgreja nesse país na manutenção das diversas formas de desigualdade, aponta uma falta de verdadeira religiosidade como elemento de degradação do povo peruano. Ela aponta a deturpação do catolicismo no Peru, defendendo, portanto, uma religião mais canônica, mesmo tendo afirmado em seu texto que a lgreja de Roma era responsável pela inexistência do divórcio e pela condição de desigualdade a que estavam submetidas as mulheres na França. O que, de certa forma, será coerente com a curiosa personagem de femme messie que adotará futuramente em sua militância política e social com um discurso de grande substrato religioso e místico.

Em meio à guerra civil que assola o país no momento de sua estância, Flora Tristan se refugia com outras mulheres de sua família no convento Santa Rosa de Arequipa, lugar da muito citada e rocambolesca história de uma prima sua, Manuela Dominga Gutiérrez, que havia forjado a própria morte, em 1831, para fugir com o médico do convento, com quem passa a viver em Lima, isolada do mundo, pária como Flora. Para ela, o convento constitui um microcosmo feminino da sociedade peruana, com toda sua desigualdade e distinção aristocrática e monárquica, inclusive com a presença de escravas que serviam 
às freiras mais ricas, que nada tinha a ver com os valores de uma república ou de uma instituição religiosa. Um local onde reinavam "em todo seu poderio as hierarquias de nascimento, de títulos, de cores de pele e de fortunas". Apesar de todas utilizarem o mesmo uniforme, uma aparente igualdade, o desdém e desprezo entre as freiras de diferentes status e cor de pele era evidente. "Vanité des vanités", alça a voz a viajante indignada (TRISTAN, 2004, p. 446-447). Na pessoa da madre superiora, Tristan estabelece uma vez mais a relação entre Igreja e política que tanto Ihe preocupava. Nascida em Sevilha, essa dama era tão educada quanto podia ser uma religiosa, e estava bastante bem instruída nos acontecimentos políticos que haviam agitado a Espanha e o Peru nos últimos vinte anos. O que significava que suas opiniões em política eram tão exaltadas quanto seu fanatismo religioso, que "ultrapassava todos os limites da razão". Sua maior aspiração, que a idade já não Ihe permitia, era ir a Madri, perdendo sua fortuna e seu nome ilustre, para, pela morte de Cristo, reestabelecer a Inquisição. Como uma metáfora da jovem república peruana, essa mulher, segundo Tristan, se havia feito obedecer e respeitar pelas religiosas governando-as com mão de ferro, mas depois de tantos anos ela não havia podido obter de nenhuma delas um sincero afeto (TRISTAN, 2004, p. 452-453).

Além do convento de Santa Rosa, Tristan também é acolhida no convento de Santa Catarina, igualmente carmelita, mas sem a austeridade de Santa Rosa. Aqui, a superiora, por sua extrema bondade e nenhum fanatismo, todo o contrário de sua homóloga espanhola de Santa Rosa, era rechaçada pelos padres que tinham autoridade sobre o convento, tendo sido destituída muitas vezes, e outras tantas vezes eleita pelas religiosas, embora a aristocracia da riqueza e a presença de escravas também reinasse aqui como em toda parte. Em lugar da Inquisição, a bondosa superiora lhe afirma que o que faria se tivesse trinta anos seria ir com ela, Flora, a ver tocar na Ópera de Paris, "as sublimes obrasprimas do imortal Rossini; uma nota desse homem de gênio era mais útil para a saúde moral e física dos povos como jamais Ihe foram úteis à religião os horríveis espetáculos dos autos de fé da santa Inquisição" (TRISTAN, 2004, p. 462). A priora de Santa Catarina é uma representação em negativo da fanática superiora de Santa Rosa, fazendo com que Flora entenda por que sua prima Manuela preferiu encenar sua própria morte para fugir deste verdadeiro sepulcro em vida, ainda que tal atitude tenha lhe custado a sua morte social. Nessa visita quase etnográfica aos conventos de Arequipa, de grande apelo literário, Flora Tristan pode construir uma comparação de duas maneiras de entender a religião e a sociedade a partir dessas duas personagens, dois tipos ideais: uma delas, vinculada às origens hispânicas, representava o despotismo e a superstição fanática da Inquisição, que criava medo sem respeito; a outra representava a doçura da influência ilustrada e polida de uma França idealizada, representada por seus valores culturais, a convivência social e o art de vivre que tornavam a vida e a política mais sociáveis e conversáveis. Curiosamente, o desejo de duas viagens também define a oposição destes modelos: uma viagem a Madri, para a restauração da Inquisição e manutenção do despotismo, e outra a Paris, para alimentar a alma com a música de Rossini. Cada viagem é um caminho conceitual que delineia uma estratégia discursiva e um itinerário político. Dois modelos civilizatórios se apresentavam aos peruanos; cabia a eles escolher. Tristan lhes adverte que o caminho hispânico é a escolha equivocada, e que havia tempo, e alguma condição, de tomar um caminho mais adequado à sociedade em geral e às mulheres em particular.

\section{A pária como alternativa e esperança}

A primeira esperança de Tristan está, curiosamente, nas mulheres indígenas, sobretudo em uma classe dessas mulheres, as rabonas, mulheres que acompanhavam os soldados 
nas guerras e que lhes preparavam o alimento, lavavam suas roupas e escolhiam os melhores terrenos para estabelecer os acampamentos. ${ }^{8}$ Andavam armadas, obrigavam os vilarejos a fornecer alimentos aos soldados e, quando não se lhes davam, os tomavam à força, "combatendo como leoas, e, por sua coragem feroz, triunfam sempre sobre a resistência" (TRISTAN, 2004, p. 431). Não recebiam nenhuma paga além do direito de pilhagem. Não falam espanhol, não são casadas, "não pertencem a ninguém e são de quem lhes quer" (TRISTAN, 2004, p. 432). Essa vanguarda militar feminina é muito superior aos homens indígenas, e mesmo aos soldados brancos. Tristan ressalta que os indígenas preferiam matar-se a tornarem-se soldados, enquanto que as rabonas abraçavam essa vida voluntariamente, "suportando fadigas, afrontando os perigos com uma coragem da que são incapazes os homens de sua raça" (TRISTAN, 2004, p. 432). O patriotismo dessas mulheres, que conseguiram incorporar-se de alguma forma à nação, lhes fazia superiores aos homens, apesar de constituir um grupo que "os discursos hegemônicos da milícia, dos intelectuais crioulos e da elite governante sistematicamente excluíam e culpavam pelo fracasso do projeto nacional" (Vanesa MISERES, 2012, p. 34). Isso significa para ela a superioridade da mulher na infância dos povos, e seria o mesmo nos povos mais avançados na civilização se elas tivessem a mesma educação que os homens.

As rabonas são párias como a própria Flora Tristan, são criaturas à parte, "endehors de tout" (TRISTAN, 2004, p. 431-432), livres da vida em sociedade, do matrimônio, da religião e exemplo das possibilidades das mulheres em liberdade; também das possibilidades de um povo na infância buscar em alguns de seus próprios valores o caminho da civilização. Aqui o modelo não é nem o mundo hispano-americano nem a llustração francesa, mas as mulheres indígenas, as párias mais afastadas da sociedade e da civilização, porém portadoras das maiores virtudes, que nelas são totalmente naturais e muito superiores do que as virtudes masculinas. As rabonas confirmam sua tese rousseauniana de que são as desigualdades criadas pela sociedade e pela civilização, e não a natureza, que tornam párias as mulheres; sem essas limitações culturais, elas eram capazes de revelar as suas qualidades. Dessa forma, Tristan se enfrenta a uma realidade da exclusão feminina na América que difere da forma como o patriarcado operava na Europa, concorrendo outro fator, que é a variação étnica da população. "Negras, índias, brancas ou mestiças, as mulheres latino-americanas sofriam de outra maneira o jugo de uma sociedade dominada pelos homens" (AMARANTE, 2015, p. 118).

Sua descrição das mulheres limenhas quase se aproxima em admiração das rabonas, mulheres que ela observa na contramão de toda uma tradição descritiva dos viajantes europeus que viam nas mulheres das Américas espanhola e portuguesa ou um ser oprimido por um orientalizado despotismo masculino, ou uma mulher lúbrica e imoral. No caso das indígenas, quase nunca nenhuma qualidade era vista nessas selvagens furiosas. A suposta liberdade na qual vivem as limenhas para os viajantes será convertida, afirma Gisela PAGÈS (201 1), "em libertinagem e seu erotismo e sensualidade darão passo à sua conversão em mulher-objeto sexual" (p. 264). Para Tristan, as mulheres de Lima se ocupam sempre da política e da intriga (TRISTAN, 2004, p. 580), e não há lugar no mundo onde as mulheres sejam mais livres; ali elas reinam sós. São mais importantes e mais bem organizadas que os homens - sejam indígenas, sejam crioulos, sempre sem remissão para ela -, se casam muito cedo, aos doze anos, têm muitos filhos, são bem formadas, embora não especialmente belas. Em suas vestes está uma das chaves de sua liberdade, algo que não existe em nenhum lugar além de Lima, e que não se parece em nada a nenhum traje espanhol: é a saya, uma saia com uma espécie de manto que envolve as costas, os braços e a cabeça

${ }^{8}$ Sobre as descrições de Flora Tristan das mulheres peruanas, cf. María Inês AMARANTE (2015). 
(TRISTAN, 2004, p. 594). O véu, que no mundo oriental significava a submissão feminina, no Peru de Tristan significava, como recorda Susan FOLEY (2004, p. 222), uma liberdade sem travas para fazer o que quisessem.

O particular interesse dessa vestimenta é que, ocultas pelo manto, as disfarçadas limenhas têm uma liberdade de movimentos no espaço público que as europeias não conheciam, sobretudo Flora Tristan, que tinha que ocultar sua condição de mulher casada para poder viajar só. Elas têm, assim, outra ordem de ideias, diferente das europeias, "que, desde sua infância, são escravas das leis, dos costumes, dos preconceitos, das modas, de tudo, enfim; enquanto que, sob a saya, a limenha é livre, goza de sua independência", podendo atuar "segundo as necessidades de sua organização" (TRISTAN, 2004, p. 603), ou seja, com a mesma liberdade que os homens. Por isso, as limenhas governam aos homens, pois são muito superiores a eles em inteligência e em força moral. O problema é que no Peru não há nenhuma instituição de educação dos sexos; sendo assim, a inteligência dessas mulheres não se desenvolve, ela convive com um coração cansado, um espírito sem cultura, a alma sem nobreza e um amor excessivo pelo dinheiro. Elas destroem, por sua absoluta falta de instrução e de leitura, "o brilhante prestígio de fascinação que seus encantos haviam produzido" (TRISTAN, 2004, p. 600).

Apesar da superioridade das mulheres peruanas, a presença da escravidão, dos costumes bárbaros e anacrônicos de tradição hispânica, como a religiosidade de aparência, as violentas corridas de touros, os execráveis conventos, impedia a moralização de sua república. A guerra civil da qual é testemunha em 1834 revela a incapacidade das elites desse "infeliz país, onde se encontram tantos homens gananciosos, de uma atroz perversidade, que, sob pretextos políticos, provocam continuamente dissensões, para ter, na guerra civil, a ocasião de pilhar seus concidadãos" (TRISTAN, 2004, p. 503). O momento no qual, em Arequipa, a República lança um bando reclamando uma contribuição forçada para a guerra é uma oportunidade para Tristan descrever, desde o balcão da casa paterna, o triste desfile dos grandes da cidade levando ao governo o "imposto revolucionário". É pela voz da prima Carmen que Flora criticará a falta de patriotismo dessas elites na figura de seu parente Mariano de Goyeneche. Ela lhe explica que seu primo é filho de um basco que fez fortuna no Peru colonial, que seu irmão Emanuel serviu como militar na Espanha e que na guerra de independência foi enviado ao Peru para defender a causa do rei, tarefa que executará, segundo Carmen, "com mais rigor que se fosse nascido castelhano". Tomou do país tudo o que pôde, tratando sua própria nação como terra conquistada, aumentando a sua fortuna. A mesma família que agora vinha, diz a indignada prima, "chorar miséria porque a república lhe demanda 6000 piastras. Ao diabo podem ir estes estrangeiros que só veem a um país novo para roubá-lo; e burlando-se daqueles que arruinaram, se retiram com seu botim para as cidades da Europa" (TRISTAN, 2004, p. 394-395). A mesma cobiça e dupla moral que, segundo Flora Tristan, faz com que seu tio, Dom Pío de Tristan, último vicerei do Peru, não lhe reconheça como legítima herdeira de seu pai, o irmão que dizia tanto amar. A mesma herança hispânica e colonial que afastava o Peru da utopia libertadora de Bolívar.

\section{O poder da pária}

Uma última personagem lhe serve para situar as mulheres peruanas e, por conseguinte, as mulheres em geral, diante do mundo da política e da ação pública, inacessível às mulheres. Trata-se de Pancha Gamarra, ou Francisca Zubiaga y Bernales (1803-1835), em seu exílio em Valparaíso, que Tristan encontra em junho de 1834 quando retornava à Europa. La Mariscala, ou doña Pancha, como era conhecida, era esposa de 
Agustín Gamarra, presidente do Peru em duas ocasiões (1 829-1 833; 1839-1841). O capítulo que reproduz esse encontro se titula l'ex-présidente de la République, uma referência à fama de mulher valente, que acompanhou seu marido na invasão da Bolívia, e ávida de poder. Para muitos, a verdadeira autoridade da República no período da primeira presidência de Gamarra. Flora, ao descrevê-la, afirma que Pancha era uma mulher fora do comum e extraordinária pela potência de sua vontade e por sua inteligência. Sua figura, de acordo com as regras com as quais medimos a beleza, diz Tristan, não era bela, mas julgando o efeito que ela produzia sobre as pessoas, ultrapassava a mais bela.

Como Napoleão, todo o império de sua beleza estava em seu olhar: quanto orgulho, quanta ousadia e penetração! Com que ascendência irresistível ele impunha o respeito, conduzia as vontades, cativava a admiração! O ser a quem Deus deu tais olhares não tem necessidade da palavra para comandar aos seus semelhantes; ele possui um poder de persuasão ao qual nos submetemos sem discutir (TRISTAN, 2004, p. 639).

Não será por acaso a referência a Napoleão, que não apenas serve de ponto de comparação para a constituição física e a ausência de beleza da Mariscala, mas ressalta o carisma e a ascendência política da senhora Gamarra, além do poder que ela adquiriu, sendo mais do que uma primeira dama, uma verdadeira presidenta. Tristan está fascinada por sua ação política e por seu espírito livre, pela possibilidade de que seu exemplo possa servir como um índice das possibilidades das mulheres no espaço público. Mas também atenta aos seus limites, já que a Mariscala está em seu exílio, abandonada e doente, pouco antes de sua morte por tuberculose. Se por um lado ela tinha virtudes heroicas admiráveis, seus defeitos a fizeram cair antes de continuar a obra de um Bolívar, que ela parecia destinada a seguir, o que poderia ter feito se seu invólucro de mulher não a tivesse impedido (TRISTAN, 2004, p. 653). Além do sexo, o que teria faltado à senhora Gamarra? "A ambição ocupava muito espaço no coração de doña Pancha para que o amor lhe fizesse um grande império; ele não foi jamais objeto de seus sérios pensamentos". Ao amor dos homens, ela respondeu com a cólera e o desprezo do orgulho ferido, perdendo as vantagens de seu sexo e atraindo o ódio de seus inimigos. Sua ambição e arrogância a levaram, quase que naturalmente, à crueldade e ao desprezo por parte de seu povo (TRISTAN, 2004, p. 653-654). Por defender uma virtude moral que as peruanas sequer possuíam, ela incluída, se tornou cruel, vingativa e orgulhosa; assim como Napoleão, não tinha a menor deferência pelo Congresso como este não tinha pelo Senado (TRISTAN, 2004, p. 655-656). Seu orgulho a levou a um abandono total em seu exílio.

Entretanto, o outono da Mariscala permite não apenas uma reflexão sobre os limites do poder, e do poder feminino, como um empoderamento de Tristan. Ao questionar a senhora Gamarra como uma alma tão forte e inteligente, pôde fazer uso da força bruta para governar, Tristan acredita ter compreendido e dominado a presidenta: nesse momento, diz ela, "eu penetrei seu pensamento; minha alma tomou possessão da sua; eu me senti mais forte do que ela, e a dominei pelo olhar..." (TRISTAN, 2004, p. 641). Nesse momento, sua narrativa parece dar início mais concretamente à personagem da líder feminista e da salvadora femme messie proletária. Sem abandonar o amor fraterno, Tristan elabora o carisma magnético, a força, determinação e inteligência que Pancha Gamarra havia utilizado para construir seu poder, sem aquilo que a autora considera como seus erros: sua arrogância, ambição e violência. Superando pela força do seu olhar a essa mirada napoleônica da Mariscala, Tristan se constrói como heroína e como líder em potência. Em seu último encontro da peregrinação pelo Peru, ela finalmente veste o figurino de sua personagem de líder política e libertadora carismática, tomando o papel que havia desempenhado a derrotada Francisca de Gamarra. 


\section{Considerações finais}

O Peru, objeto de sua peregrinação inicial em busca de fortuna e identidade, com seu périplo pelo deserto de Arequipa como ritual de passagem, se revela não uma Canaã, uma terra de promissão, mas uma extensão do mundo hispânico e toda a sua inferioridade se torna uma distopia. "No Novo Mundo eu era, ainda, pária como no outro" (TRISTAN, 2004, p. 172). Os tempos se anulam e a revolução de independência não provoca no país uma superação das raízes coloniais. A redenção da pária não vai ser a terra paterna; a compreensão de suas desigualdades, a liberdade fugaz e incompleta de suas mulheres Ihe dará o caminho de salvação do apostolado socialista e feminista, a compreensão de que sua situação de pária se devia à sua condição de mulher e, como compreenderá mais adiante, de proletária. A distopia americana, ao final, se transforma na utopia feminista e socialista da femme messie dos proletários que descobre em seu último combate com a presidenta exilada a força carismática de seu olhar, de sua natureza de liderança. Sua narrativa de viagem é mais do que um relato autobiográfico, ou uma "aventura interior meramente pessoal"; para Mónica SZURMUK (2007), as mulheres utilizam o relato de viagem para "discutir temas de grande conteúdo político" (p. 13). Como afirmei anteriormente, Flora Tristan, por meio de sua viagem iniciática ao Peru, reconstrói sua identidade; não apenas consolida sua "ideia de si e sua situação como mulher, como também a confirma em sua identidade francesa", ainda que de uma forma exótica, como define Thompson (2012, p. 268).

O relato de Tristan é um relato político e um "artefato cultural", como ressalta Mills (2005, p. 12). Artefato que, quando escrito por uma mulher, revela uma série de "tensões discursivas em sua produção e recepção às quais as mulheres escritoras têm que negociar, de forma muito diferente dos homens" (MILLS, 2005, p. 5). Flora Tristan era consciente dessas pressões específicas que a mulher viajante sofria, assim como todas as demais viajantes, sobretudo aquelas que publicavam seus relatos. Sua especificidade foi ter extrapolado os limites da negociação, que acantonavam os relatos femininos na esfera privada e autobiográfica, utilizando a própria biografia como elemento discursivo de construção de um projeto político que questionava os constrangimentos impostos às mulheres. Uma vindicação pelo direito de utilizar o espaço público ultrapassando o lugar de pária tradicionalmente destinado à mulher.

A peregrinação pelo Peru lhe fornece também um método, que ela ensaia em sua narrativa de viagem e no projeto de associação de apoio às mulheres viajantes, no qual Flora Tristan aposta pela libertação feminina por duas vias principais: pelo conhecimento do mundo que a viagem permite, tomando contato com as realidades sociais e as desigualdades; e pela liberdade de movimentos que, por vezes, poderia significar um salvador anonimato, num primeiro momento, e um empoderamento da mulher, quando ela se torna livre para se deslocar por onde quiser e aprender o mundo pela própria experiência, sem a necessidade de sayas ou pseudônimos masculinos. Tudo isso se consegue, ainda, pelo exemplo que a narrativa de viagem proporciona para o convencimento e ilustração das mulheres e dos proletários, os párias do mundo, liderados pela profetisa feminista, investigadora social e reformadora, construída literária e cuidadosamente por seu relato autobiográfico e por suas peregrinações ao Peru, a Londres ou pelo interior da França. Ela percebe em sua peregrinação ao Peru que sua narrativa de viagem fundamenta suas ideias e argumentos pela força da experiência direta e pela sinceridade da autobiografia, suprindo sua escassa instrução literária ou intelectual. A viagem é sua forma de libertação, de aprendizado, de crescimento pessoal e de construção narrativa de si que supera todas as limitações que impõem a sua condição de mulher, de divorciada, de ilegítima e de 
aristocrata decaída. Por meio da viagem, Tristan reconstrói sua vida segundo uma personagem heroica e romântica, tornando-se uma crítica social formada pela experiência do deslocamento, uma verdadeira "escritora filosófica de viagens" (THOMPSON, 2012, p. 264). Em seu primeiro itinerário, Flora Tristan reconhece que a viagem pode ser um princípio de libertação.

\section{Referências}

AMARANTE, María Inês. "Flora Tristan e os retratos das mulheres latino-americanas no início do século XIX". Revista Sures, n. 5, p. 115-137, fev. 2015.

BLOCH-DANO, Evelyne. Flora Tristán. La mujer mesías. Madri: Maeva, 2002.

BRAHIMI, Denise. "Femmes voyageuses au XIXe siècle: la possibilité d'un classement?". In: ESTELMANN, Frank; MOUSSA, Sarga; WOLFZETTEL, Friedrich (Eds.). Voyageuses européennes au XIXe siècle. Identités, genres, codes. Paris: Presses de l'Université de Paris-Sorbonne, 2012. p. 257-272

DEPETRIS, Carolina. El héroe involuntario. Frédéric de Waldeck y su viaje por Yucatán. Mérida: Universidad Nacional Autónoma de México, 2014.

ETTE, Ottmar. Literatura en movimiento. Espacio y dinámica de una escritura transgresora de fronteras. Madri: CSIC, 2008.

EUBEN, Roxanne Leslie. Journeys to the other shore. Muslim and Western Travelers in Search of Knowledge. Princeton: Princeton University Press, 2006.

FAINI, Carla M. Debating the Nation. Print Culture and the Consolidation of The Peruvian Republic: From Flora Tristan to the Revista de Lima 1838-1863. 1997. (Dissertação) Departamento de Espanhol e Português, Stanford University, Michigan, Ann Arbor, EUA.

FOLEY, Susan. "In search of 'liberty': politics and women's rights in the travel narratives of Flora Tristan and Suzanne Voilquin". Women's History Review, Londres, Routledge, v. 13, n. 2, p. 211-231, 2004.

FRANCO, Stella Maris Scatena. Peregrinas de outrora: viajantes latino-americanas no século XIX. Florianópolis: Mulheres; Santa Cruz do Sul: EDUNISC, 2008.

GABAUDE, Florence. "Les pérégrinations d'une paria: initiation, observation, révélation". The French Review, v. 71, n. 5, p. 809-819, abr. 1998.

GROGAN, Susan K. "Flora Tristan and the Moral Superiority of Women". In: French Socialism and Sexual Difference. Women and the New Society, 1803-44. Londres: Palgrave Macmillan, 1994. p. 155-196.

HOLANDA, Sérgio Buarque de. Raízes do Brasil. 20.ed. Rio de Janeiro: José Olympio, 1988.

KRAMER, Lloyd. "Victor Jacquemont and Flora Tristan: Travel, Identity and the French Generation of 1820". History of European Ideas, Londres, Pergamon Press, v. 14, n. 60, p. 789-816, 1992.

LE HUENEN, Roland. "Pérégrinations d'une paria: voyage, bâtardise, écriture". The Romanic Review, Columbia University, v. 98, n. 1, p. 71-82, 2007.

Le récit de voyage au prisme de la littérature. Paris: Presses de l'Université de ParisSorbonne, 2015

MALENFANT, Brigitte. L'horizon autobiographique du récit de voyage de Flora Tristan, Les Pérégrinations d'une Pária (1838). Memória apresentada para obter a Maîtrise ès Arts (Études Françaises). Montreal: Universidade de Montreal, 1997.

MICHAUD, Stéphane. "Flora Tristan Américaine". The Romanic Review, Columbia University, v. 98 , n. 1, p. 7-21, 2007.

MILLS, Sara. Discourses of Difference. An Analysis of Women's Travel Writing and Colonialism. Londres; Nova lorque: Routledge, 2005. 
MONICAT, Bénédicte. Itinéraires de l'écriture au feminin. Voyageuses du 19e siècle. Amsterdã; Atlanta: Rodopi, 1996.

MISERES, Vanesa. "On a Republic in Ruins: Flora Tristan's Peregrinations of a Pariah and the Role of the Rabonas in Nineteenth-Century Peru". Review: Literature and Arts of the Americas, Londres, Routledge, v. 45, n. 1, p. 29-36, 2012.

PAGÈS, Gisela. "La mujer limeña en el imaginario de los viajeros europeos, siglos XVIII-XIX". In: ESPITIA, Leonardo (Org.). Tierras prometidas: de la Colonia a la Independencia. Bellaterra: CECE, Universidad Autónoma de Barcelona, 2011. p. 263-280.

PAUK, Barbara. "Contesting national and gender boundaries: Flora Tristan's promenades dans Londres". Nineteenth-Century French Studies, University of Nebraska Press, v. 37, n. 1-2, p. 123-135, 2008.

PÉREZ-MEJÍA, Ángela. A Geography of Hard Times. Narratives about Travel to South America, 1780-1849. Nova lorque: State University of New York Press, 2004.

PERROT, Michelle. Des femmes rebelles. Olympe de Gouges, Flora Tristan, George Sand. Túnis: Elyzad, 2014.

PRATT, Mary Louise. Os olhos do império. Relatos de viagem e transculturação. Bauru: EDUSC, 1999.

REID, Martine. "Flora Tristan: 'De la nécessité de faire un bon accueil aux femmes étrangères'". Lectora. Revista de Dones i Textualitat, Barcelona, Universitat de Barcelona, n. 20, p. 107 $117,2014$.

ROUANET, Maria Helena. Eternamente em berço esplêndido: a fundação de uma literatura nacional. São Paulo: Siciliano, 1991.

SZURMUK, Mónica. Miradas cruzadas: narrativas de viaje de mujeres en Argentina, 18591930. México: Instituto Mora, 2007.

TALBOT, Margaret. "An emancipated voice: Flora Tristan and Utopian Allegory". Feminist Studies, v. 17, n. 2, p. 219-239, 1991.

THOMPSON, Christopher W. French Romantic Travel Writing: Chateaubriand to Nerval. Oxford: Oxford University Press, 2012.

TORRÃO FILHO, Amilcar. A arquitetura da alteridade: a cidade luso-brasileira na Literatura de Viagem (1783-1845). São Paulo: Hucitec/FAPESP, $2010 \mathrm{a}$.

. "Le catholicisme luso-brésilien selon les voyageurs français du XIXème siécle". Travaux de Littérature, Genebra, Droz, v. XXIV, p. 207-217, 2011.

TRISTAN, Flora. Nécessité de faire un bon accueil aux femmes étrangères. Paris: l'Harmattan, 1988.

. Pérégrinations d'une paria. Paris: ActesSud, 2004.

VARIKAS, Eleni. A escória do mundo: figuras do pária. São Paulo: EDUNESP, 2014.

[Recebido em 23/03/2016, reapresentado em $30 / 01 / 2017$ e aprovado em 12/04/2017]

\section{Flora Tristan's Pilgrimages of a Pariah and the Construction of a Feminist}

Abstract: Pérégrinations d'une paria is Flora Tristan's initiatory Peru travelog published in 1838, in which she seeks her paternal protection. This is the first publication that makes Flora Tristan a known author. In this article, I defend the idea that Pérégrinations d'une paria, like hers Nécessité de faire un bon accueil aux femmes étrangères (1835), formulate a theory of social struggle, undertaken by Tristan on her return to Europe, which has as a starting point women's freedom acquired by freedom of movement, the ability to travel and to compare her own society with other societies, acquiring social and political consciousness in this process.

Keywords: Flora Tristan; Travelers; Feminism 
Amilcar Torrão Filho (amilcartorrao@gmail.com) atualmente é Professor de História do Brasil, Teoria da História e História Moderna na Pontifícia Universidade Católica de São Paulo, Professor da Pós-Graduação Lato Sensu e Stricto Sensu, além de membro do conselho editorial da revista Urbana. Revista Eletrônica do CIEC, Revista Projeto História e Revista Iberoamericana de Urbanismo. Tem experiência na área de História, com ênfase em História do Brasil Colônia, História do Brasil Império, História Moderna e Contemporânea, Teoria da História e Historiografia, atuando principalmente nos seguintes temas: urbanismo, cidades e vilas, história urbana, São Paulo, Literatura de Viagem, história colonial e história do Império. É coordenador do Núcleo de Estudos da Alteridade com Karen Macknow Lisboa. 